\title{
A decade of belowground reorganization following multiple disturbances in a subtropical wet forest
}

\author{
Yit Arn Teh • Whendee L. Silver • \\ Frederick N. Scatena
}

Received: 29 October 2008 / Accepted: 4 February 2009 / Published online: 25 February 2009

(C) The Author(s) 2009. This article is published with open access at Springerlink.com

\begin{abstract}
Humid tropical forests are dynamic ecosystems that experience multiple and overlapping disturbance events that vary in frequency, intensity, and spatial extent. Here we report the results of a 10-year study investigating the effects of forest clearing and multiple hurricanes on ecosystem carbon reservoirs, nutrient pools and vegetation. The aboveground plant community was most heavily affected by multiple disturbances, with the 9-year-old stands showing high rates of hurricane-induced mortality relative to surrounding forest. Belowground pools were less affected. Live fine root biomass fluctuated in response to multiple disturbances, but returned to pre-disturbance
\end{abstract}

Responsible Editor: Erik A. Hobbie.

Y. A. Teh · W. L. Silver

Ecosystem Sciences Division,

Department of Environmental Science,

Policy, and Management, University of California,

137 Mulford Hall \#3114,

Berkeley, CA 94720-3114, USA

F. N. Scatena

Department of Earth and Environmental Science,

University of Pennsylvania,

240 S. 33rd Street, Hayden Hall,

Philadelphia, PA 19104-6316, USA

Present Address:

Y. A. Teh $(\triangle)$

School of Geography \& Geosciences,

University of St. Andrews,

St. Andrews KY16 9AL Scotland, UK

e-mail: yat@st-andrews.ac.uk levels after 10 years. Soil $\mathrm{C}$ was resilient to clearing and hurricanes, probably due to the large pool size and high clay content. Soil P fluctuated over time, declining during periods of rapid plant recovery and growth. With the exception of $\mathrm{K}$, base cations recovered within 2 years following clearing and showed little response to hurricane disturbance.

Keywords Biogeochemical cycling · Gap dynamics . Hurricanes · Succession · Land-use change · Luquillo Mountains Puerto Rico

\section{Introduction}

Disturbance is a natural component of terrestrial ecosystems and influences the properties of populations, communities, and patterns of biogeochemical cycling (Picket and White 1985; Sousa 1984; Hubbell et al. 1999; Denslow et al. 1998; Matson et al. 1987). Our knowledge of ecosystem responses to disturbance often comes from the aboveground response to single disturbance events. These range from investigations of small-scale gap dynamics (Denslow et al. 1998; Ostertag 1998; Brokaw 1987) and manipulative experiments studying the effects of land-use change (Ewel et al. 1981; Matson et al. 1987; Aide et al. 1995; Silver et al. 2004), to large-scale natural events, such as hurricanes (Zimmerman et al. 1995; Ostertag et al. 2003). However, tropical ecosystems commonly 
experience multiple overlapping disturbance events that vary in frequency, intensity, and spatial extent. For example, tropical forests in the Caribbean are subject to anthropogenic disturbances such as land clearing or agricultural conversion (Aide et al. 2000; Silver et al. 2004), as well as natural disturbances such as hurricanes or landslides (Walker 1991; Walker et al. 1991, 1996). These disturbances create a complex matrix of disturbance, succession, and repeated disturbance on the landscape (Silver et al. 1996; Uriarte et al. 2004; Ostertag et al. 2005; Pascarella et al. 2004; Beard et al. 2005).

The effects of multiple disturbances on terrestrial ecosystems may not be additive, but synergistic in nature, causing non-linear changes in successional trajectories or ecosystem recovery patterns (Platt and Connell 2003; Platt et al. 2002; Paine et al. 1998; Payette and Delwaide 2003). For example, boreal forests in Canada subject to multiple perturbations including fire, insect attack, and clear-cutting diverged from expected successional trajectories to form heathlands dominated by shrubs and lichens, rather than forests dominated by conifers and mosses (Payette and Delwaide 2003). Likewise, subtropical savannas in the USA with anthropogenically altered fire regimes saw unexpected increases in pine mortality following the passage of Hurricane Andrew (Platt et al. 2002). It is possible that tropical forests may experience similar "ecological surprises" in the future, given the increasing pace of land clearing (Nepstad et al. 1999) and predicted changes in storm frequency and intensity due to climate warming (Emanuel 2005).

In this paper, we report the results of a 10 -year study investigating the combined effects of land clearing and multiple hurricanes on forest $\mathrm{C}$ pools, soil nutrient reservoirs and vegetation structure in a subtropical wet forest in Puerto Rico. Existing studies have tended to focus on the consequences of multiple disturbances for vegetation structure and aboveground processes (Uriarte et al. 2004; Ostertag et al. 2005; Pascarella et al. 2004). Less is known about the impacts on belowground processes (Silver et al. 1996; Olander et al. 1998). We addressed two principal questions: (1) what are the effects of forest clearing and multiple hurricanes on vegetation structure after 10 years of ecosystem reorganization? And (2) how do multiple aboveground disturbances influence $\mathrm{C}$ and nutrient pools?

\section{Methods}

Study site and hurricane descriptions

The study site was located in the tabonuco (Dacryodes excelsa Vahl; Burseraceae) forest zone of the Bisley Research Watersheds in the Luquillo Experimental Forest Long-Term Ecological Research site (LEF), Puerto Rico $\left(18^{\circ} 3^{\prime} \mathrm{N}, 65^{\circ} 8^{\prime} \mathrm{W}\right)$. The tabonuco forest is classified as a subtropical wet forest (sensu Holdridge et al. 1971) and occurs between 250 and $450 \mathrm{~m}$ above sea level. It receives approximately $3,500 \mathrm{~mm}$ of rainfall per year with no prolonged wet or dry season (Scatena 1989). The soils are part of the Humatus-Zarzal-Cristal complex and are classified as clayey, mixed isothermic, Epiaquic Tropohumults or Palehumults (Ultisols) (Beinroth 1982; Johnston 1992). The underlying parent material is volcanoclastic sandstone, rich in ferromagnesium minerals, that weather to form soils high in clays and $\mathrm{Fe}$ or $\mathrm{Al}$ oxides, but low in silica and free bases (Scatena 1989; Bonnet 1939). The dominant silicate clays are degraded illites that have lost a substantial portion of K (Jones et al. 1982).

This study was designed to investigate the longterm effects of small-scale land clearing on aboveand belowground plant dynamics, soil nutrient losses and biogeochemical cycling at multiple time scales (Scatena et al. 1993; Silver and Vogt 1993; Silver et al. 1996). The location of the experiment in an LTER site allowed us to compare the effects of additional disturbances (in this case hurricanes) on the previously cleared land with effects on old growth forest. We report on the same study sites used in Scatena et al. (1993), Silver and Vogt (1993), and Silver et al. (1994, 1996). In June 1989, two $32 \times 32 \mathrm{~m}$ experimental gaps were created by cutting all plant material using chainsaws and removing it by hand (Scatena et al. 1993; Silver and Vogt 1993; Silver et al. 1996). One experimental plot, hereafter referred to as the Lower Plot, is located below the monitored portion of Bisley Watershed 2. The second experimental plot, referred to as the Upper Plot, is located adjacent to Bisley Watershed 1, and is approximately $400 \mathrm{~m}$ from the Lower Plot. Slope, aspect, topography and preclearing forest structure were similar in both cleared plots (Scatena et al. 1993; Silver et al. 1994). The highly dissected topography of the area made it difficult to establish equivalent $32 \times 32 \mathrm{~m}$ control 
plots and simultaneously control for factors such as slope and aspect, which strongly influence the biogeochemistry of this ecosystem (Scatena et al. 1993; Silver et al. 1994). Instead we established two $16 \times 32 \mathrm{~m}$ reference plots and pooled the data from the two areas into one control treatment. This enabled us to control for slope and aspect, and maintain a similar sampling regime to that of the cleared plots. Both control sub-plots were established in intact forest adjacent to the cleared plots, and separated from the manipulated plots by approximately $75 \mathrm{~m}$ of intact forest in areas with no run-off from the cleared plots (upslope or located over a small ridge).

Hurricane Hugo passed over the LEF on September 17 and 18, 1989, 11 1/2 weeks after the initial clearing. This hurricane was a category 4 storm on the Saffir-Simpson Scale with sustained winds of $166 \mathrm{~km}$ $\mathrm{h}^{-1}$ and gusts of $194 \mathrm{~km} \mathrm{~h}^{-1}$ (Scatena and Larsen 1991). By this time, the cleared plots had begun to regenerate and damage consisted primarily of the deposition of fine litter that was blown in from the surrounding forest and a reduction in the gap-to-forest edge effect. The control plots experienced defoliaton and some treefalls in addition to the litter deposition (Silver et al. 1996). Hurricane Georges passed over the LEF 9 years later on September 21, 1998. This hurricane was a category 3 storm with sustained winds of $184 \mathrm{~km} \mathrm{~h}^{-1}$ and gusts of $241 \mathrm{~km} \mathrm{~h}^{-1}$ (Ostertag et al. 2003, 2005). Damage to the control and cleared plots consisted largely of defoliation and branch snaps. The slower wind speeds and gusts for Hurricane Hugo compared to Georges arose from the fact that Hugo made landfall closer to the LEF than Georges, with the eye of the storm passing over the LEF during the 1989 event (Scatena and Larsen 1991; Ostertag et al. 2003, 2005).

\section{Aboveground vegetation sampling}

All trees in the cleared plots with a diameter at breast height (dbh) of $\geq 2.5 \mathrm{~cm}$ were identified to species (Little and Wadsworth 1989), tagged, their dbh measured and their locations mapped in 1988, 1989, 1994, and 1999. The trees mapped and measured in 1988 were felled and the remains used to develop species-specific allometric equations (Scatena et al. 1993). Pioneers were tagged and measured in 1989 and 1994. We included height measurements in 1999 and calculated biomass using species-specific equa- tions developed for the Bisley Watersheds (Scatena et al. 1993). Tree heights were determined to the top of each tree using a clinometer, with corrections made for slope when necessary. Tissue $\mathrm{C}$ was assumed to be $50 \%$ of mass. Tissue $\mathrm{N}$ concentrations were estimated using extensive species- and part-specific (i.e., leaf, branch, bole) nutrient data collected from other studies in this forest (Ovington and Olson 1970; Scatena et al. 1993).

Tree mortality was calculated based on the number of tagged trees that died between the 1994 and the 1999 surveys. Trees killed by Hurricane Georges were identified separately from others that died due to senescence or other external forcings (i.e., disease, insect attack). These hurricane-killed trees were identified as those that bore visible signs of wind damage, such as defoliation, broken boles, snapped branches or uprooting of tree trunks. Delayed mortality was determined by repeatedly inspecting the trees in the cleared plots in the 6-8 month period following Hurricane Georges. Importance values were calculated as the sum of relative stem density and relative basal area for each species. Relative stem density was calculated by dividing the number of stems for each species in the cleared plots by the total number of stems, while relative basal area was determined by dividing the basal area of each species in the cleared plots by total basal area. These fractional values were then converted to percentages and added together to generate importance values for each species.

Understory plants, defined as ground cover and saplings $<2.5 \mathrm{~cm} \mathrm{dbh}$, were characterized in ten $1 \times$ $1 \mathrm{~m}$ quadrats in each cleared plot during the 1999 survey. All understory plants were identified to the species level. Visual estimates of percent cover were made on a species basis for each quadrat. Each quadrat was then destructively harvested. Plant material was oven-dried at $65^{\circ} \mathrm{C}$ for at least $48 \mathrm{~h}$ and weighed for dry mass. Relative species dominance was determined by calculating the relative biomass of each understory species, and ranking them by order of abundance. Plant materials were bulked into three categories within each plot for nutrient analyses as follows: (1) dominant species, (2) subdominant species and (3) all other species. Dominant and subdominant species were the two most abundant species by mass.

All plant material was ground in a Wiley mill and re-dried. The ground plant material was then analyzed 
for $\mathrm{C}$ and $\mathrm{N}$ content using a CE Instruments NC 2100 elemental analyzer (Thermo Fisher Scientific, Inc., Waltham, Massachusetts) at the University of California at Berkeley (UCB). Additional sub-samples were digested in $\mathrm{H}_{2} \mathrm{SO}_{4}$ using a modified ParkinsonAllen digest and analyzed for $\mathrm{Ca}, \mathrm{Mg}, \mathrm{K}, \mathrm{Al}$ and $\mathrm{P}$ on a DCP Spectrascan V spectrophotometer (Thermo Fisher Scientific, Inc., Waltham, Massachusetts) at the International Institute for Tropical Forestry, Puerto Rico (IITF).

Fine root mass

Fine roots were collected at $0,2,5,9$, and 12 monthly increments during the first year of the experiment in order to capture the immediate- and short-term responses of live and dead root pools to multiple disturbances. Sampling frequency declined in the second year to two time points and from thence to annual increments (in June/July). Samples were collected and analyzed according to the protocols described by Silver and Vogt (1993) and Silver et al. (1996). Samples were taken from nine different locations in each of the cleared plots ( $n=9$ per plot) and from four locations in each of the control plots $(n=4$ per plot). Roots were sorted by diameter size class $(<2 \mathrm{~mm}$ and $2-5 \mathrm{~mm})$ and by live or dead categories (Silver and Vogt 1993; Silver et al. 1996). Sorted roots were oven dried at $65^{\circ} \mathrm{C}$ and weighed to determine dry mass. The roots were subsequently ground and analyzed for $\mathrm{C}$ and $\mathrm{N}$ content using a $\mathrm{CE}$ Instruments NC 2100 elemental analyzer at UCB. The low mass of root samples precluded cation and $\mathrm{P}$ analysis. Only fine root $(<2 \mathrm{~mm}$ diameter $)$ data are reported in this paper.

\section{Soil and forest floor sampling}

Soils and forest floor were collected according to the sampling regime described by Silver et al. (1996). Soils were collected from 15 randomly located sites stratified by latitudinal and longitudinal bands in each of the cleared plots using a $2.5 \mathrm{~cm}$ diameter soil corer $(n=15$ per plot). Soils were collected in 1989 prior to clearing and intensively for the first 2 years following clearing; these data are reported in Silver and Vogt (1993) and Silver et al. (1996). Soils were then collected at annual intervals after that until 1999. Here we report on annual soil sampling from 1989-1999, with samples collected from the $0-10 \mathrm{~cm}$ soil horizon. Soils were also collected from seven different locations from each of two control plots. Samples were stored at $4^{\circ} \mathrm{C}$ until they were extracted within 24 to $48 \mathrm{~h}$ after collection. For exchangeable $\mathrm{Ca}, \mathrm{Mg}, \mathrm{K}$ and $\mathrm{Al}$, approximately $4 \mathrm{~g}$ of fresh soil from the $0-10 \mathrm{~cm}$ depth was extracted with $55 \mathrm{ml}$ of $1 \mathrm{M} \mathrm{NH}_{4} \mathrm{Cl}$ using a vertical vacuum extractor (Silver et al. 1996). Samples were then analyzed on a DCP Spectrascan V spectrophotometer at IITF. For P, Fe and Mn approximately $5 \mathrm{~g}$ of soil from the $0-10 \mathrm{~cm}$ layer was extracted with $50 \mathrm{ml}$ of a modified Olsen solution $\left(0.01 \mathrm{M} \mathrm{NH}_{4}, 0.01 \mathrm{M}\right.$ EDTA, $0.25 \mathrm{M} \mathrm{NaHCO}$ ) using a vertical vacuum extractor and analyzed on a DCP Spectrascan spectrophotometer. Soils from the $0-10 \mathrm{~cm}$ horizon collected from 1989 to 1995 were analyzed for C using the Walkley-Black procedure (Nelson and Sommers 1982). Soils collected from 1996 to 1999 were analyzed for C and N using a LECO 2000 CNS analyzer at IITF, or a CE Instruments NC 2100 elemental analyzer at UCB. Walkley-Black $\mathrm{C}$ values were corrected for incomplete oxidation of organic $\mathrm{C}$ (Nelson and Sommers 1982). A subset of the archived soil samples $(n=95)$ were analyzed using both the LECO 2000 CNS and the CE Instruments NC 2100 to calibrate the two instruments. Soil $\mathrm{C}$ and $\mathrm{N}$ values reported here are corrected for differences between procedures and analytical instrumentation. WalkleyBlack $\mathrm{C}$ values were corrected using the percent recovery data reported by Nelson and Sommers (1982). Data collected from the subset of samples analyzed by both the LECO CNS and CE Instruments NC 2100 were regressed against each other to generate an appropriate calibration factor $\left(r^{2}=0.96, P<0.0001\right)$.

Soil nutrient concentrations were calculated using bulk density values reported in Silver et al. (1994). The forest floor was sampled annually from $1315 \times 15 \mathrm{~cm}$ quadrats in each cleared plot. Samples were oven-dried at $65^{\circ} \mathrm{C}$, ground in a Wiley mill and re-dried. Ground material was analyzed for $\mathrm{C}$ and $\mathrm{N}$ using a CE Instruments NC 2100 elemental analyzer at $\mathrm{UCB}$, digested and analyzed for $\mathrm{Ca}, \mathrm{Mg}, \mathrm{K}, \mathrm{Al}$ and P on a DCP Spectrascan V spectrophotometer at IITF.

Statistical analysis

Statistical analyses were performed using JMP IN Version 5.1.2 (SAS Institute Inc.) and SYSTAT 
Version 8.0 (SPSS Inc.) software. The data were $\log$ transformed where appropriate to meet the assumptions of analysis of variance (ANOVA). Residuals from all analyses were checked for normality and homogeneity of variances. Changes in the pool size of roots, soil $\mathrm{C}$, exchangeable cations, and $\mathrm{P}$ were analyzed using repeated-measures analysis of variance (ANOVA). Treatment (control, cleared), time, and their interaction were the explanatory variables. Differences among plots (Control, Upper Plot, Lower Plot) were explored using one-way ANOVA. Means comparisons were conducted using Fisher's Least Significant Difference (LSD) test at the $\alpha=0.05$ level. All errors referred to in the text are standard errors.

\section{Results}

Aboveground vegetation dynamics

The clearcut plots had been recently created when the first hurricane struck, and thus aboveground vegetation was sparse, low to the ground, and there was no detectable mortality (Silver et al. 1996). Nine years after land clearing, the plots were dominated by the pioneer tree Cecropia schreberiana and the tree fern Cyathea arborea (Fig. 1). Other important colonists included Psychotria berteriana and Schefflera actinophylla. The understory was dominated by the monocots Heliconia bihai and Ichnanthus palens (data not shown). Tree size class distribution followed a reverse-J-shape distribution with the greatest number of stems in the 2.5 to $4.9 \mathrm{~cm}$ size class (Fig. 2). Stem density and basal area both increased most rapidly in the first 5-years following clearing (Table 1). In the subsequent 5-year period, the stands began to thin, and stem densities declined by approximately $40 \%$. Basal area showed only a small increase during this time period. Tree height increment averaged over the first 10 years of succession was $0.9 \pm 0.1 \mathrm{~m} \mathrm{year}^{-1}$. Tree mortality averaged $9 \pm 2 \%$ year $^{-1}$, after subtracting Hurricane Georges-induced deaths. Mortality from Hurricane Georges averaged $13 \pm 7 \%$, with the Lower Plot experiencing greater mortality (20\%) than the Upper Plot (6\%). Cecropia schreberiana, Cyathea arborea, and Psychotria berteriana suffered the highest mortality, accounting for $44 \%, 19 \%$, and $19 \%$, respectively, of all hurricane-induced deaths. Hurricane Georges greatly increased the rate of mortality for these three colonists. Cecropia schre-
Fig. 1 Importance values for different tree species in the cleared plots. Relative stem density for each species was calculated as a percentage of all stems, while relative basal area for each species was calculated as a percentage of total basal area. Importance values for each species were determined by adding relative stem density and relative basal area together

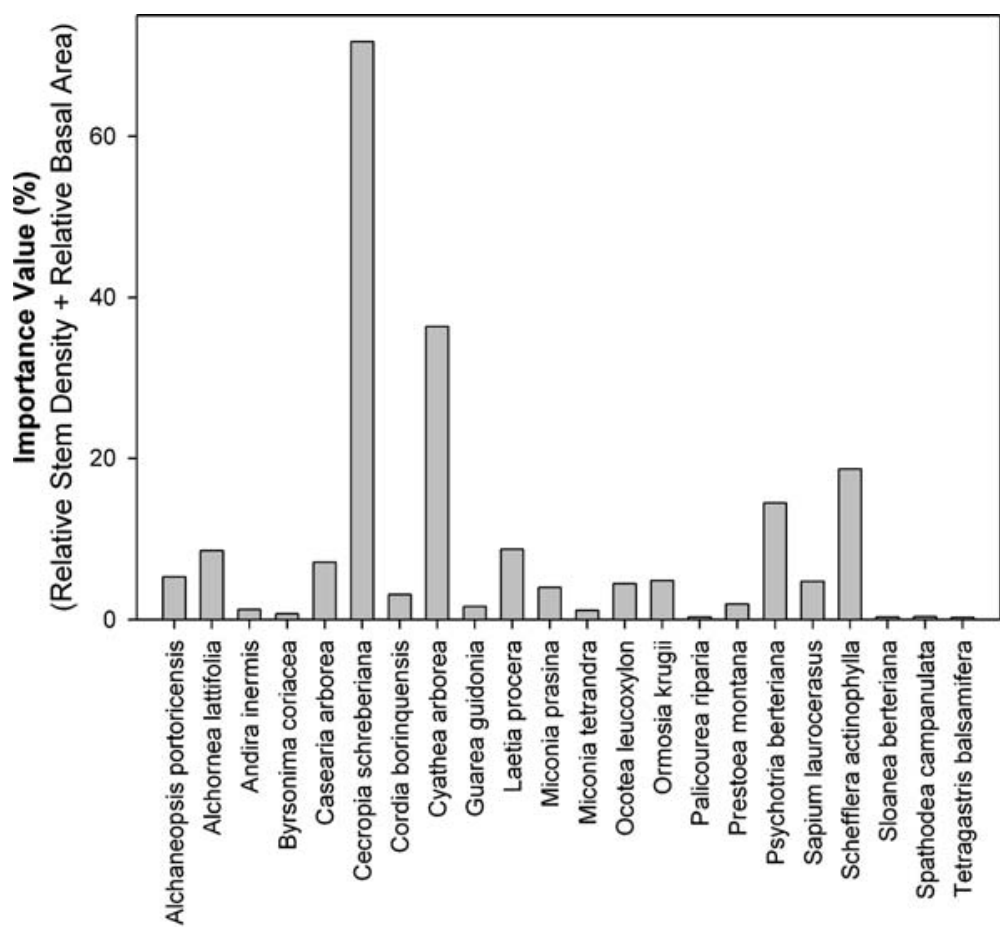

Tree Species 
Fig. 2 Frequency distribution for stems of different size classes in the cleared plots

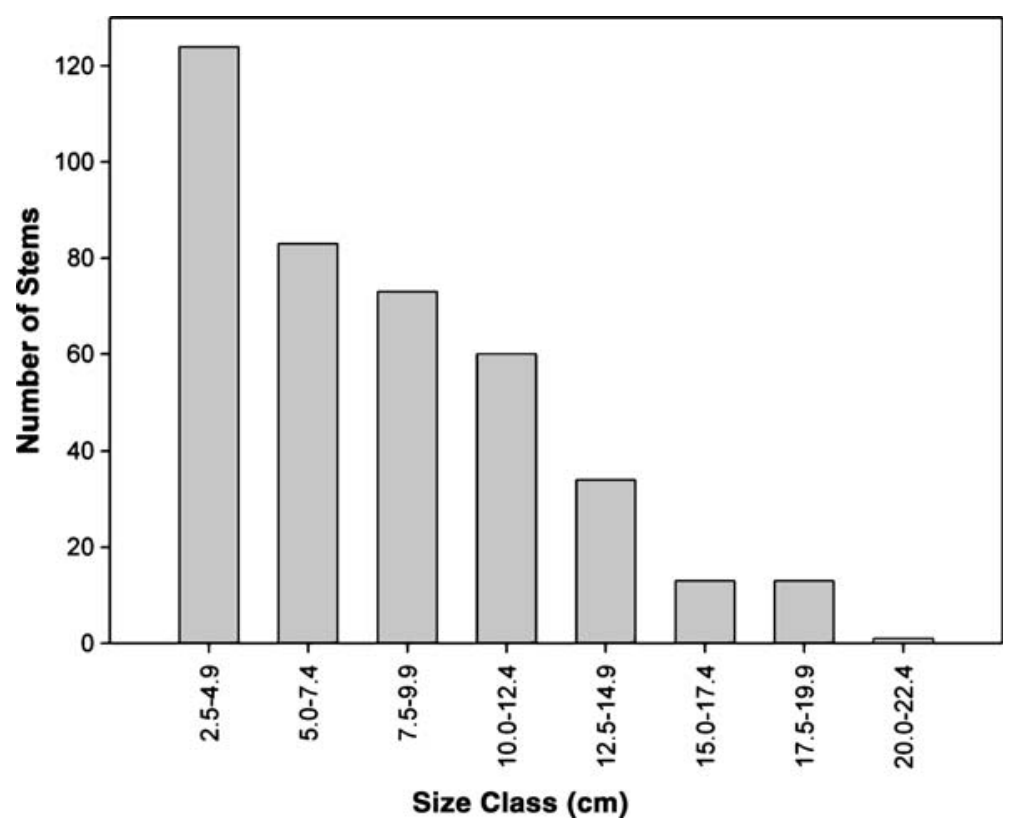

beriana deaths rose from a rate of $10 \%$ to $13 \%$ year $^{-1}$ during 1999; likewise, Cyathea arborea deaths increased from $7 \%$ to $33 \%$ year $^{-1}$ and Psychotria berteriana deaths rose from $8 \%$ to $27 \%$ year $^{-1}$.

Fine roots

Live and dead fine root mass showed different dynamics in the control and cleared plots. In the cleared plots, live fine root mass began to decline immediately following aboveground biomass removal with a corresponding increase in dead fine root mass (Fig. 3A, Table 3). Live fine root mass remained significantly below pre-treatment levels, at $<50 \%$ of initial values, from 9 months after clearing until 9 years afterwards $\left(F_{15,258}=9.0, P<0.0001\right.$; Fisher's LSD, $P<0.05)$. Live fine roots only showed a significant increase to pre-treatment levels in 1999. Dead fine root mass increased significantly above initial levels 9 months after clearing and remained elevated above pre-treatment levels for the entire duration of the experiment $\left(F_{15,259}=2.6, P<0.001\right.$; Fisher's LSD, $P<0.05)$.

In the control plots, live fine root biomass declined significantly after Hurricane Hugo. Live fine root mass fell to approximately one-tenth of pre-hurricane levels over a period of 6 to 9 months after the storm (Fig. 3B, Table 3; Fisher's LSD, $P<0.05$ ). Live fine root biomass in the control plots fluctuated significantly over the subsequent 10 years, showing a roughly sinusoidal pattern (Fig. 3B; $F_{14}, 55=1.9$, $P<0.05)$. Dead fine root mass rose gradually over a period of 17 months following Hurricane Hugo, reaching a transient maximum approximately 20 months after the beginning of the experiment (Fig. 3B; $F_{14},{ }_{56}=2.1, P<0.05$; Fisher's LSD, $P<0.05)$. Live fine root mass in the control did not appear to respond to Hurricane Georges and was
Table 1 Stem density and basal area in the cleared plots in 1994 and 1999

Standard errors in parentheses

\begin{tabular}{llllc}
\hline Plot & Survey year & Years since harvest & Tree density $\left(\mathrm{m}^{-2}\right)$ & $\begin{array}{c}\text { Basal area } \\
\left(\mathrm{m}^{2} \mathrm{ha}^{-1}\right)\end{array}$ \\
\hline Lower plot & 1994 & 5 & 0.38 & 13.71 \\
Upper plot & 1994 & 5 & 0.32 & 8.52 \\
Mean & & & $0.35(0.03)$ & $11.11(2.60)$ \\
Lower plot & 1999 & 10 & 0.15 & 12.39 \\
Upper plot & 1999 & 10 & 0.24 & 12.23 \\
Mean & & & $0.20(0.05)$ & $12.31(0.08)$ \\
\hline
\end{tabular}


Fig. 3 Live and dead fine root biomass in the cleared (a) and in the control plots (b). Circles represent live roots and triangles represent dead roots. Bars represent standard errors

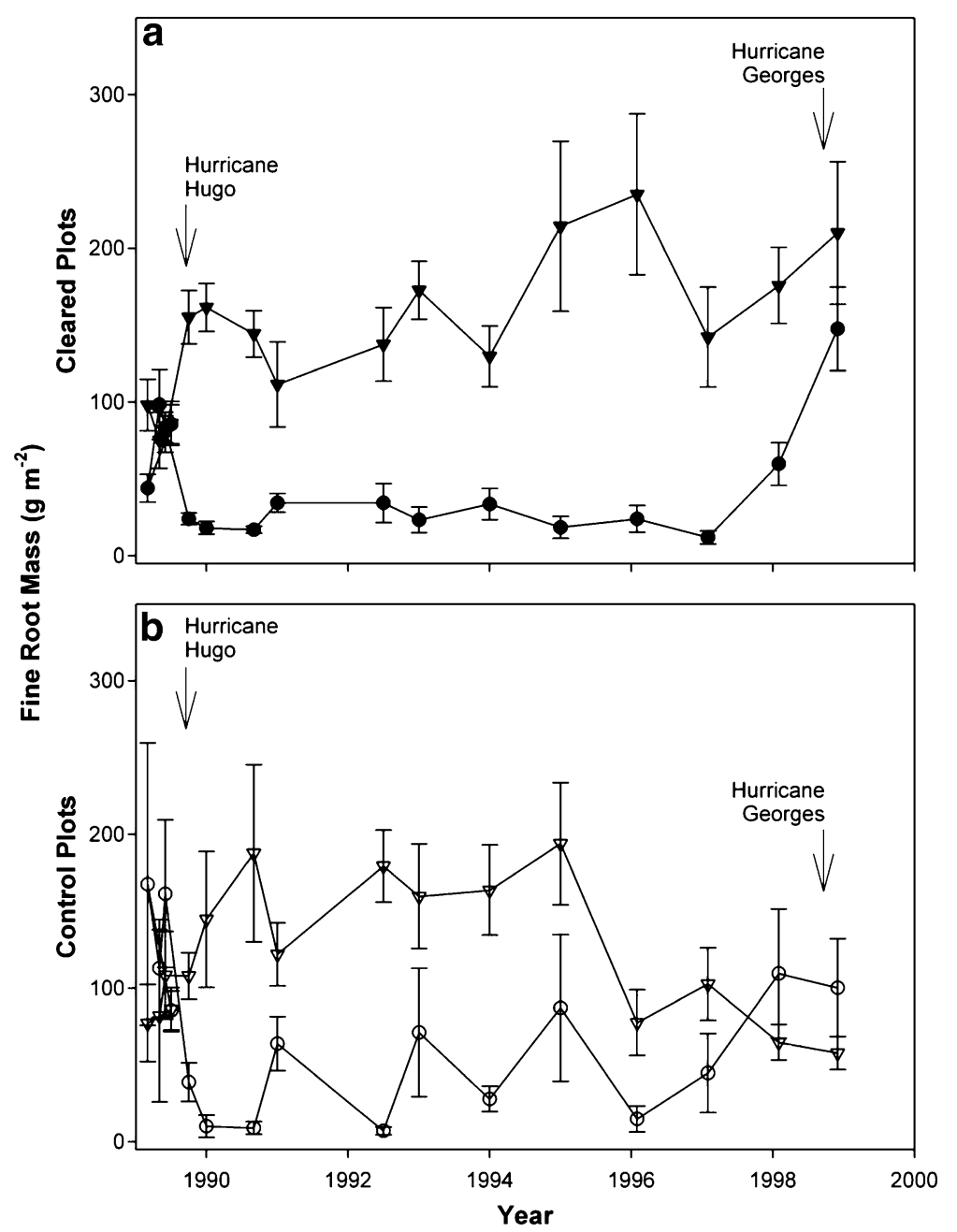

similar to initial biomass levels (Table 3). Dead fine root mass returned to initial values between 6 and 9 years after the start of the experiment.

\section{Carbon pools}

Soil C pools showed greater variability amongst plots than over time within plots (Fig. 4). For example, Lower Plot soils always contained significantly less C than either the Upper Plot or Control, based on data pooled from all sampling periods (Fig. 4; $F_{2}, 349=$ 30.0, $P<0.0001$; Fisher's LSD, $P<0.05$ ).

The $\mathrm{C}$ pool in tree biomass was approximately half that of the $\mathrm{C}$ stored in the surface $10 \mathrm{~cm}$ of soils (Table 2). The average $\mathrm{C}$ content of live vegetation (i.e., trees, herbaceous understory, live fine roots) was approximately $16.4 \mathrm{Mg} \mathrm{C} \mathrm{ha}{ }^{-1}$ or $\sim 11 \%$ of initial values (Scatena et al. 1993). This is probably a slight underestimate of the total plant biomass accrued over 10 years, as our budget did not include coarse roots.

\section{Phosphorus}

One-way ANOVA indicates that $\mathrm{P}$ varied significantly among plots $\left(F_{2,409}=18.5, P<0.0001\right.$; Fisher's LSD, $P<0.05$ ), with the control showing the highest overall $\mathrm{P}$ content $\left(8.2 \pm 0.4 \mathrm{~kg} \mathrm{P} \mathrm{ha}{ }^{-1}\right)$, the Upper Plot intermediate levels of $\mathrm{P}\left(6.9 \pm 0.2 \mathrm{~kg} \mathrm{P} \mathrm{ha}{ }^{-1}\right)$, and the Lower Plot the least P $\left(5.7 \pm 0.2 \mathrm{~kg} \mathrm{P} \mathrm{ha}^{-1}\right)$. Soil $\mathrm{P}$ responded differently in the cleared plots compared to the controls (Fig. 5). In the cleared plots, P rose significantly above initial levels from 1991 to 1994 $\left(F_{10}, 280=4.0, P<0.0001\right.$; Fisher's LSD, $\left.P<0.05\right)$. Phosphorus returned to initial levels in 1995 and remained close to pre-treatment concentrations for the remainder of the experiment (Fisher's LSD, $P>0.05$ ). 
Fig. 4 Soil organic carbon $\left(\mathrm{Mg} \mathrm{ha}^{-1}\right)$ in the $0-10 \mathrm{~cm}$ soil depth for cleared (a) and control (b) plots over a decade of ecosystem reorganization. Closed circles represent the Lower Plot, closed triangles represent the Upper Plot and open squares represent the control. Bars represent standard errors

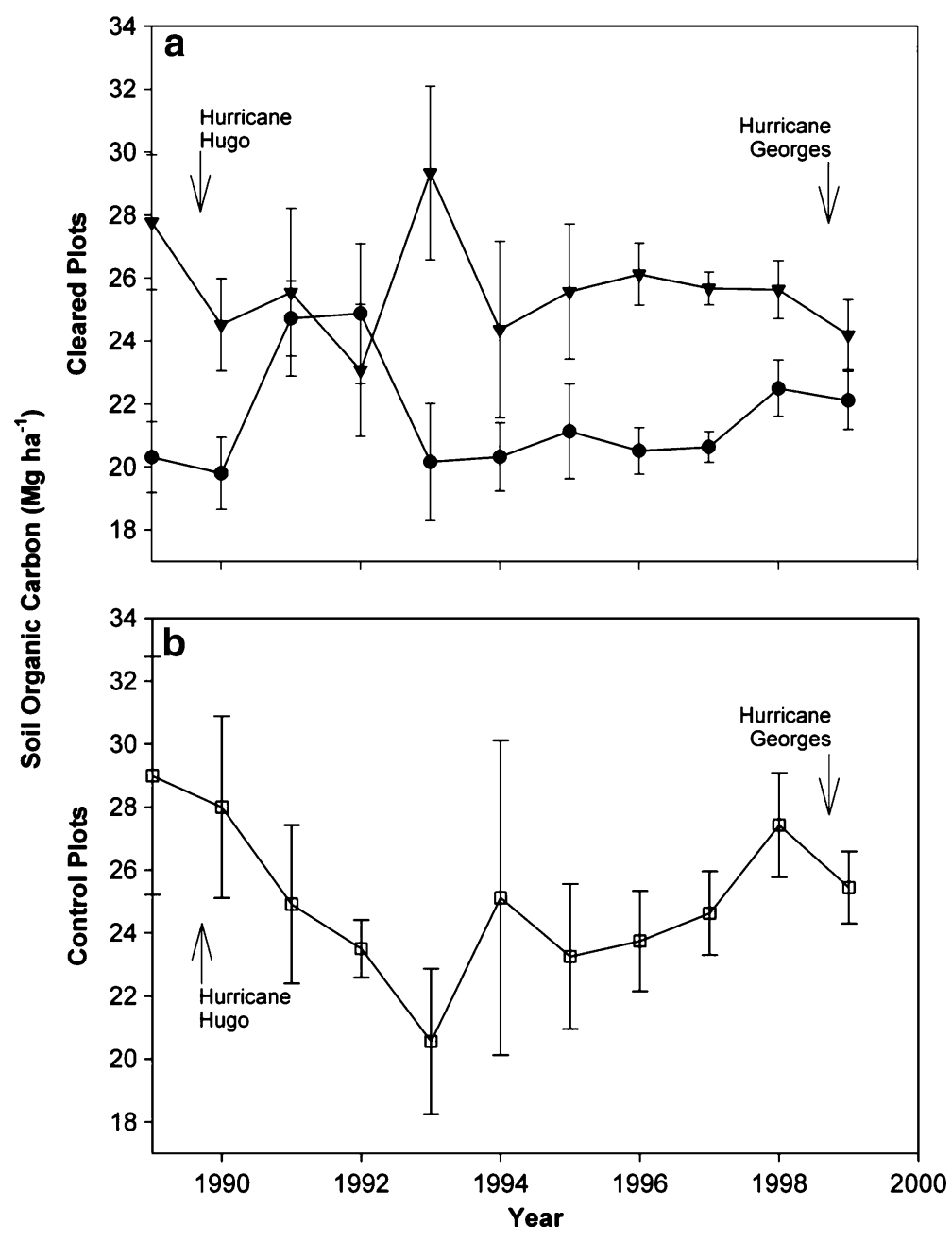

In the control plots, $\mathrm{P}$ began a gradual decline from 1990 to 1994 , culminating in a significant reduction in $\mathrm{P}$ below initial levels in $1995\left(F_{10,129}=2.1, P<\right.$ 0.05 ; Fisher's LSD, $P<0.05)$. Phosphorus remained significantly below initial concentrations for the remainder of the observation period, never returning to initial values (Fisher's LSD, $P<0.05$ ). When data were pooled from the cleared and control plots, we

Table 2 Distribution of organic matter and carbon pools after 10 years of ecosystem reorganization

\begin{tabular}{lccccc}
\hline & \multicolumn{2}{l}{ Lower plot } & & \multicolumn{2}{c}{ Upper plot } \\
\cline { 2 - 3 } Compartment & Organic matter $\left(\mathrm{Mg} \mathrm{ha}^{-1}\right)$ & Carbon $\left(\mathrm{Mg} \mathrm{ha}^{-1}\right)$ & & Organic matter $\left(\mathrm{Mg} \mathrm{ha}^{-1}\right)$ & $\mathrm{Carbon}\left(\mathrm{Mg} \mathrm{ha}^{-1}\right)$ \\
\hline Trees live & 28.40 & 14.20 & 30.23 & 15.11 \\
Forest floor & 5.58 & 2.50 & 4.23 & 1.93 \\
Herbaceous & 2.36 & 1.02 & 1.36 & 0.59 \\
Roots live & 1.43 & 0.64 & 1.53 & 0.69 \\
Roots dead & 2.26 & 0.95 & 1.94 & 0.86 \\
Soil $(0-10 \mathrm{~cm})$ & 51.56 & 23.85 & 68.85 & 31.84 \\
Total & 91.59 & 43.16 & 108.13 & 51.01 \\
\hline
\end{tabular}


Fig. 5 Available phosphorus in the $0-10 \mathrm{~cm}$ soil depth for the cleared and control plots over a decade of ecosystem reorganization. Closed circles represent cleared plots and open circles represent the control. Bars represent standard errors

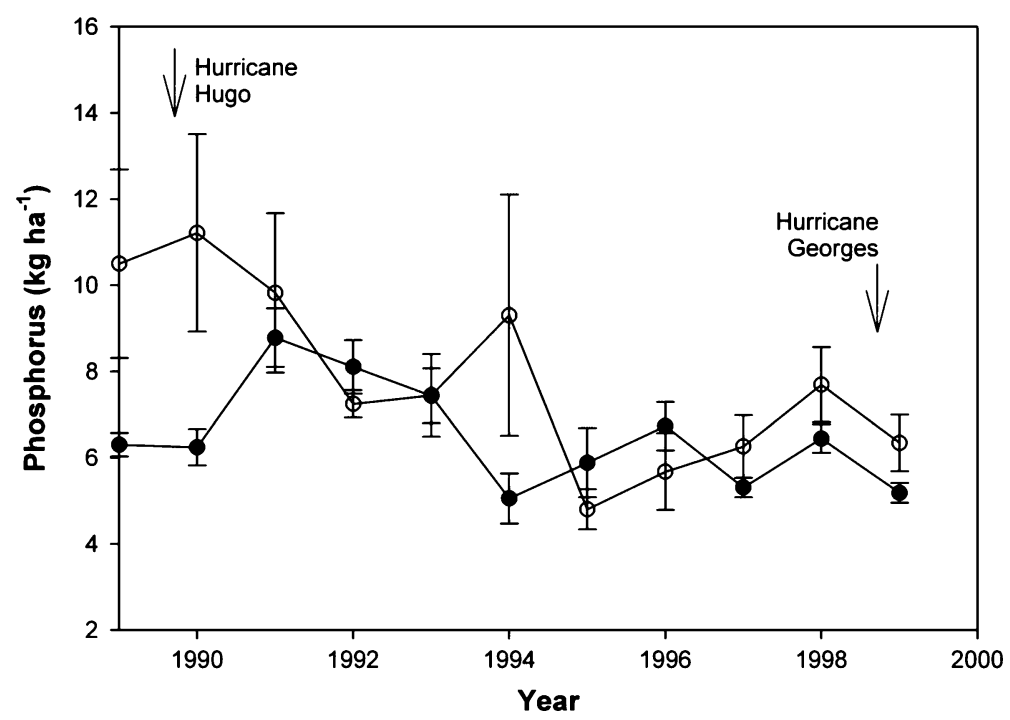

found that available soil $\mathrm{P}$ was positively correlated with soil $\mathrm{C}$ ( $r^{2}=0.41, P<0.001$; data not shown).

Cation dynamics and cation exchange capacity

Effective cation exchange capacity (ECEC), as measured by the sum of measured exchangeable cation concentrations, behaved similarly in the cleared and control plots (Fig. 6A). ECEC increased significantly above initial levels during the first year of the experiment (Fisher's LSD, $P<0.05$ ), after which ECEC fell significantly below initial levels in 1991 (Fisher's LSD, $P<0.05$; see also Fig. 6A). In the control, ECEC returned to initial levels in 1992, while in the cleared plots, ECEC rose above initial levels in the same year. ECEC varied interannually between 1993 and 1998, but did not deviate significantly from initial values. ECEC once again rose significantly above initial levels in 1999, in the wake of Hurricane Georges (Fisher's LSD, $P<0.05$ ). In the cleared plots, base cation concentrations fell significantly in 1990 (Fig. 6B; Fisher's LSD, $P<0.05$ ), while concentrations in the control plots did not differ significantly from initial concentrations (Fig. 6B; Fisher's LSD, $P>0.05$ ). From 1991 onwards, the dynamics of base cations in the cleared and control plots mirrored each other.

Calcium and $\mathrm{Mg}$ concentrations rose significantly above initial concentrations in 1992, and remained significantly above initial levels for the duration of our observations (Fig. 7A, B, Fisher's LSD, $P<0.05$ ). The one exception to this was in 1997, when $\mathrm{Ca}$ in the cleared plots fell to initial concentrations (Fig. 7A), while $\mathrm{Mg}$ in the cleared plots fell below initial levels (Fig. 7B). Calcium and $\mathrm{Mg}$ concentrations were correlated with each other across all the plots $\left(r^{2}=0.63 ; P<0.001\right.$; data not shown). In the cleared plots, $\mathrm{K}$ fell significantly below initial levels in 1990 and 1991 (Fig. 7C, Table 3; Fisher's LSD, $P<0.05$ ). Exchangeable $\mathrm{K}$ recovered briefly to initial concentrations during 1992, and then fell once again below initial levels from 1993 to 1998 (Fisher's LSD, $P<0.05$ ), showing modest interannual variations (Fig. 7C). Potassium showed a significant increase after Hurricane Georges (Fig. 7C, Table 3; Fisher's LSD, $P<0.05)$. In the control plots, $\mathrm{K}$ showed no significant change following Hurricane Hugo. Potassium fluctuated slightly over time, but did not vary significantly from initial values from 1991 to 1998. Potassium in the control, like the cleared plots, increased significantly above initial levels after Hurricane Georges in 1999 (Fig. 7C, Table 3; Fisher's LSD, $P<0.05)$.

Exchangeable Al behaved similarly in the cleared and control plots, increasing by two-four times above baseline levels in the first year after Hurricane Hugo (Fig. 7D; Fisher's LSD, $P<0.05$ ). Exchangeable Al subsequently fell significantly below initial levels in 
Fig. 6 Total cation (a), exchange Al (b), and base cation (c) concentrations in the $0-10 \mathrm{~cm}$ soil depth for cleared and control plots over a decade of ecosystem reorganization. Closed circles represent cleared plots and open circles represent the control. Bars represent standard errors

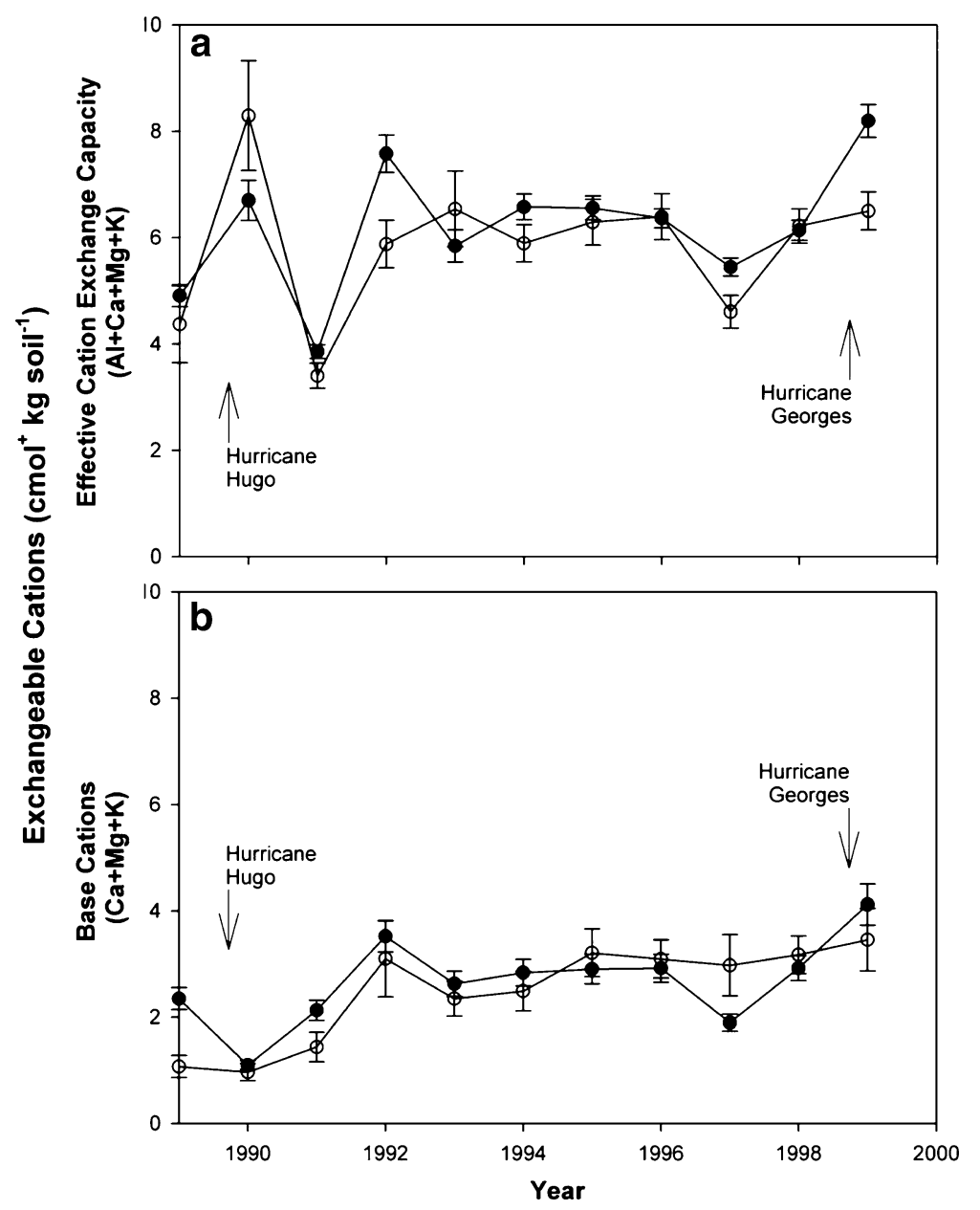

1991 (Fig. 7D; Fisher's LSD, $P<0.05$ ), before returning to initial levels in 1992 (Fig. 7D; Fisher's LSD, $P>0.05)$.

\section{Discussion}

Regeneration of aboveground vegetation

Colonization following land clearing was primarily by pioneer species such as Cecropia schreberiana, Cyathea arborea, Psychotria berteriana, and Schefflera actinophylla. This was expected given the relatively large size of the clearings $\left(1,024 \mathrm{~m}^{2}\right)$, which favor light-demanding pioneers over more slowgrowing mature forest species that tend to thrive in smaller light openings $\left(<200 \mathrm{~m}^{2}\right)$ (Brokaw 1985, 1987, 1998). The reverse-J-shape of the size class distribution suggests that the cleared plots were composed of several cohorts of different ages (Smith et al. 1997). Pioneers such as Cecropia schreberiana and Cyathea arborea colonized the plots immediately after clearing, while more shade-tolerant, late successional species, such as Casearia arborea, Guarea guidonia, Ocotea leucoxylon, Prestoea montana, Sloanea berteriana, and Tetragastris balsamifera established later (Scatena et al. 1996; Chinea 1999; Thompson et al. 2002; Scatena \& Silver pers. obs.).

Tree densities and basal area showed the greatest increase in the first 5 years after clearing. During the subsequent 5-year period, stem densities declined significantly and basal area showed only a modest increase $(\sim 10 \%)$. This implies that colonization was greatest during the first 5 years of succession, after which self-thinning and Hurricane Georges drastically reduced the density of the initial colonists. Basal area at 10 years after land clearing and two hurricanes was higher than average compared to other wet tropical 

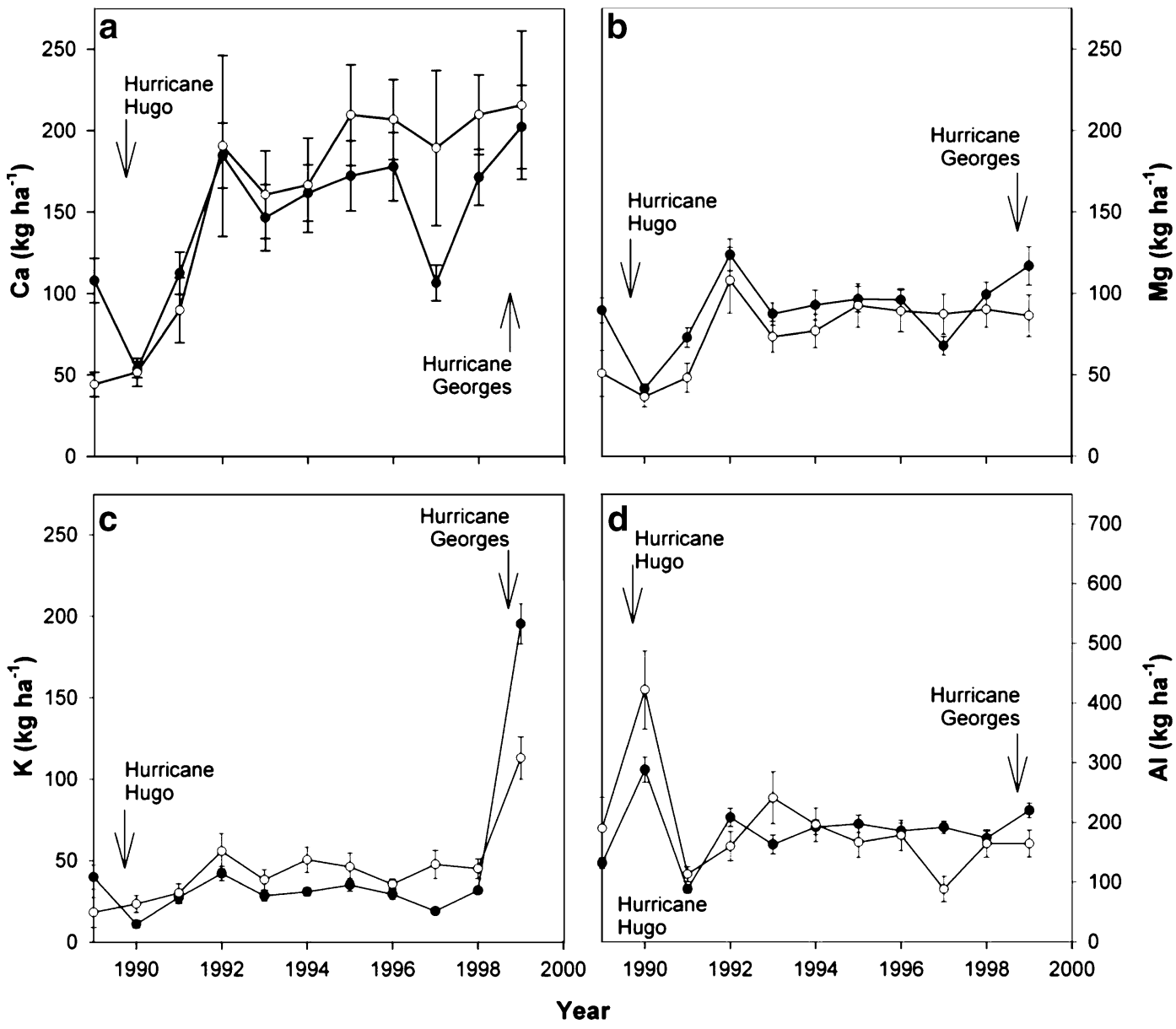

Fig. $7 \mathrm{Ca}(\mathbf{a}), \mathrm{Mg}(\mathbf{b}), \mathrm{K}(\mathbf{c})$, and $\mathrm{Al}$ (d) abundance in the $0-10 \mathrm{~cm}$ soil depth for cleared and control plots over a decade of ecosystem reorganization. Closed circles represent cleared plots and open circles represent the control. Bars represent standard errors

forests recovering from light to moderate land-use (Guariguata and Ostertag 2001; Aide et al. 1996, 2000). This indicates that the changes wrought by these particular disturbances (small-scale clearing, large-scale hurricane disturbance) had less impact on plant colonization and growth than other common land uses in the region.

Mortality rates were high $(9 \pm 2 \%)$ relative to more mature forests $(<5 \%)$, although this was not surprising given the high turnover frequently observed in early successional stands (Lugo and Scatena 1996). Hurricane Georges-induced mortality was significantly greater in the cleared plots $(13 \pm 7 \%)$ than in mature subtropical wet forests (5.2-7.5\%; see Ostertag et al. 2005) or after Hurricane Hugo (7-9\%; see Walker 1991; Walker et al. 1991; Zimmerman et al. 1995).
The higher mortality observed in the cleared plots was probably due to the dominance of the overstory by fast-growing pioneer species that are generally less resistant to storm damage (Zimmerman et al. 1995; Ostertag et al. 2005). This lack of resistance arises from a variety of factors, including differences in stem and root architecture, wood density, and elastic modulus (Ostertag et al. 2005). The differing rates of Hurricane Georges-induced mortality amongst the dominant early colonists (i.e., Cecropia schreberiana, Cyathea arborea, Psychotria berteriana) indicate that these species show varying degrees of resistance to hurricane damage. Of the three species, Cecropia schreberiana showed the greatest resistance to wind damage and lowest mortality, with deaths rising from a background rate of $10 \%$ to $13 \%$ year $^{-1}$ immediately 
Table 3 Live fine root and nutrient pools in the cleared and control plots before and after Hurricanes Hugo and Georges

\begin{tabular}{|c|c|c|c|c|}
\hline Plot \& ecosystem pool & Pre-Hugo & 1-year post-Hugo & Pre-Georges & 1-year post-Georges \\
\hline \multicolumn{5}{|l|}{ Cleared } \\
\hline Live fine root mass $\left(\mathrm{g} \mathrm{m}^{-2}\right)$ & $85.5(12.7) \mathrm{a}$ & $18.0(4.1) b$ & $59.6(13.9) \mathrm{a}$ & $147.7(27.3) b$ \\
\hline Soil organic matter $\left(\mathrm{Mg} \mathrm{ha}^{-1}\right)$ & $22.8(0.6)$ & $22.2(1.2)$ & $24.1(0.7)$ & $23.2(0.7)$ \\
\hline Phosphorus $\left(\mathrm{kg} \mathrm{ha}^{-1}\right)$ & $6.3(0.3)$ & $6.2(0.4)$ & $6.4(0.3)$ & $5.2(0.2)$ \\
\hline Calcium $\left(\mathrm{kg} \mathrm{ha}^{-1}\right)$ & $66.6(9.5)$ & $107.9(13.7)$ & $171.4(17.3)$ & $202.2(25.6)$ \\
\hline Magnesium $\left(\mathrm{kg} \mathrm{ha}^{-1}\right)$ & $89.5(7.6)$ & $41.3(2.9)$ & $99.3(7.6)$ & $116.8(11.9)$ \\
\hline Potassium $\left(\mathrm{kg} \mathrm{ha}^{-1}\right)$ & $39.8(7.4) \mathrm{a}$ & $11.0(2.3) \mathrm{b}$ & $31.7(1.9) \mathrm{a}$ & $195.4(12.3) b$ \\
\hline \multicolumn{5}{|l|}{ Control } \\
\hline Live fine root mass $\left(\mathrm{g} \mathrm{m}^{-2}\right)$ & $110.8(29.1) \mathrm{a}$ & $10.1(7.3) b$ & $109.6(42.0)$ & $100.3(31.9)$ \\
\hline Soil organic matter $\left(\mathrm{Mg} \mathrm{ha}^{-1}\right)$ & $28.6(1.6)$ & $28.0(2.9)$ & $27.4(1.6)$ & $25.4(1.1)$ \\
\hline Phosphorus $\left(\mathrm{kg} \mathrm{ha}^{-1}\right)$ & $10.0(1.0)$ & $11.2(2.3)$ & $7.7(0.9)$ & $6.3(0.7)$ \\
\hline Calcium $\left(\mathrm{kg} \mathrm{ha}^{-1}\right)$ & $44.1(7.6)$ & $51.6(8.6)$ & $209.8(24.5)$ & $215.6(45.5)$ \\
\hline Magnesium $\left(\mathrm{kg} \mathrm{ha}^{-1}\right)$ & $50.9(14.1)$ & $36.4(6.2)$ & $90.1(11.0)$ & $86.2(12.7)$ \\
\hline Potassium $\left(\mathrm{kg} \mathrm{ha}^{-1}\right)$ & $18.2(9.2)$ & $23.4(5.2)$ & $45.1(6.1) \mathrm{a}$ & $113.0(13.1) \mathrm{b}$ \\
\hline
\end{tabular}

Standard errors in parentheses. Lower case letters denote statistically significant differences between means (Fisher's LSD, $P<0.05$ )

following Hurricane Georges. By contrast, Cyathea arborea and Psychotria berteriana mortality rose by $\sim 4$-fold during the same period.

Root dynamics following multiple disturbances

Live fine root biomass was severely affected by multiple disturbances. Land clearing reduced live fine root biomass by $\sim 40 \%$, while subsequent damage from Hurricane Hugo further lowered live fine root biomass to $15-20 \%$ of the original pool size during the first year after the storm (Silver and Vogt 1993). Live fine root biomass in the cleared plots remained low ( $<50 \%$ of initial mass) for almost a decade, only returning to initial values in 1999 . The control plots also experienced a decline in live root biomass following Hurricane Hugo, with reductions approaching $\sim 90 \%$ of initial values 6 to 9 months after the storm. However, unlike the treatment plots, we saw transient increases in live fine root biomass over 10 years, when live root biomass was $75-100 \%$ of initial values. The live (albeit severely damaged) trees in the control plots thus retained the capacity to produce as many live roots after Hugo as before it, although actual live root biomass fluctuated. New recruitment into the cleared plots, on the other hand, did not appear capable of producing as much live root biomass as the controls, presumably because of the lower aboveground biomass and changes in plant community structure.

These findings are consistent with other experiments in wet tropical forests which suggest that live fine root biomass is lower in treefall gaps compared to adjacent mature forest (Ostertag 1998; Denslow et al. 1998). More interesting and unique, however, is the observation that live fine root biomass was suppressed for so many years following disturbance. Other studies saw higher or equivalent live fine root biomass in recovering tropical forests of a similar age to ours (Cavelier et al. 1996; Cuevas et al. 1991; Raich 1980, 1983). The low fine root biomass in the treatment and control plots following multiple disturbances contrasts with patterns of aboveground recovery, which showed a steady rise in the first 5 years following Hurricane Hugo (Scatena et al. 1996).

One explanation for this phenomenon is that regenerating vegetation allocated more photosynthate to aboveground biomass than to roots. In the cleared plots, this may be due to inherent differences in allocation patterns amongst pioneers and late successional trees, with light-demanding pioneers allocating more to aboveground growth (Chapin 1980, 1991). In the mature forest, competition for light and space may have forced the smaller trees-which accounted for most of the vegetation that regenerated after 
Hurricane Hugo (Scatena et al. 1996) — to allocate to stem and leaf development. Greater nutrient availability after Hurricane Georges may also have favored lower allocations to roots as plants were able to meet their nutrient demands without investing heavily belowground (Chapin 1991; Bloom et al. 1985). In addition, the decrease in structural complexity and layering in the adjacent forest may have led to lower fine root biomass in surface soils.

Soil carbon, nutrients, and cation exchange capacity

Soil C, phosphorus and cations all showed differential responses to multiple disturbance. Soil $\mathrm{C}$ in the cleared and control plots did not change significantly following biomass removal and multiple hurricanes. This suggests that soil $\mathrm{C}$ losses (microbial respiration, leaching losses) balanced inputs from hurricanederived organic debris. The high clay, Fe-rich soils typical of this region have the capacity to sequester $\mathrm{C}$ in stable aggregates, decreasing the susceptibility of soil $\mathrm{C}$ losses with disturbance and land cover change (Marin-Spiotta et al. 2008). The large size of the soil $\mathrm{C}$ pool, relative to potential inputs and outputs, may have decreased our ability to detect losses from these disturbances. The soil $\mathrm{C}$ pool was much larger than any other potential sources of C-approximately 42 times the size of the live fine root pool and 13 times greater than the forest floor. The flux of $\mathrm{C}$ from hurricane debris into the soil $\mathrm{C}$ pool was also probably quite low. Pulse labeling studies conducted elsewhere using ${ }^{14} \mathrm{C}$-labelled organic matter suggest that only a small fraction of decaying organic matter is actually transferred to soil $\mathrm{C}$ pools, with the majority lost as $\mathrm{CO}_{2}$ (Fu et al. 2000; Kisselle et al. 2001).

Phosphorus, in contrast, showed a clear response to land clearing and hurricane disturbance. Elevated $\mathrm{P}$ during the first 2 years after cutting and Hurricane Hugo was probably due to a combination of low $\mathrm{P}$ demand from plants and high $\mathrm{P}$ inputs from hurricane debris. The cleared plots were in an early phase of plant succession and the new colonists were probably too small to significantly deplete soil $\mathrm{P}$ below initial concentrations. The subsequent decline in $\mathrm{P}$ from 1992 to 1995 was likely the result of increased plant uptake, as trees grew larger during a rapid period of forest re-growth following Hurricane Hugo (Scatena et al. 1996). The observed correlation between available $\mathrm{P}$ and soil $\mathrm{C}$ is consistent with other observations from this site, and likely reflects sorption or incorporation of labile $\mathrm{P}$ to Fe-coated organic matter (Silver et al. 1994).

Effective cation exchange capacity appeared to respond strongly to hurricane disturbance. Increases in ECEC immediately after Hurricane Hugo and Hurricane Georges suggests that the number or density of cation exchange sites rose after hurricane disturbance. Transient increases in either $\mathrm{Al}$ and $\mathrm{K}$ after the two hurricanes were probably a response to increased cation exchange capacity; positively charged $\mathrm{Al}^{3+}$ and $\mathrm{K}^{+}$ions may have entered the soil solution to balance the increased number of negatively charged surface exchange sites (Sposito 1989; Sollins et al. 1988). Small changes in the amount or quality of soil organic matter could have induced changes in the surface chemistry and reactivity of these Fe and Al-rich soils (Sposito 1989; Sollins et al. 1988; Silver et al. 1994; Tiessen et al. 1994). This interpretation is supported by work from Hubbard Brook Experimental Forest, where investigators observed increases in ECEC after forest clearing that were linked to changes in SOM chemistry, but were independent of SOM quantity (Johnson et al. 1997).

Base cations $(\mathrm{Ca}, \mathrm{Mg}, \mathrm{K})$ in the cleared plots declined in the first year after clearing and Hurricane Hugo, while remaining close to initial values in the control plots. Leaching losses probably drove this pattern. Plant biomass in the treatment plots was very low in the first year after clearing, with new tree saplings and herbaceous plants acting as a relatively weak sink for base cations. Elevated $\mathrm{NO}_{3}{ }^{-}$concentrations in the first year after clearing favored accelerated export of base cations as well (Silver and Vogt 1993). Finally, land clearing removed a substantial fraction of the base cation capital from the cleared plots and disrupted patterns of internal cycling via litterfall (Johnson et al. 1988; Scatena et al. 1993). Over longer ( $>1$ year) time scales, individual base cations showed different recovery trajectories. Calcium and $\mathrm{Mg}$, for example, recovered to initial concentrations by the second year after clearing. The strong correlation between $\mathrm{Ca}$ and $\mathrm{Mg}\left(r^{2}=0.63\right)$ concentrations probably reflects the fact that the two divalent cations have similar cycling patterns, physiochemical properties, and transport. Potassium, on the other hand, showed a slower recovery, remaining below initial concentrations for at least 9 years after the initial disturbance of land clearing. This was 
probably driven by reduced $\mathrm{K}$ inputs or accelerated $\mathrm{K}$ losses; the latter is supported by stream water chemistry measurements, which indicate that $\mathrm{K}$ losses from the solum were elevated for more than 9 years after Hurricane Hugo (McDowell et al. 1996; Schaefer et al. 2000).

The apparent resilience of soil $\mathrm{C}$ and nutrient pools to multiple disturbances is due, in part, to the fact that little or no soil erosion occurred within our study sites. Watershed-scale measurements of stream water chemistry showed transient (i.e., 1-2 year) increases in $\mathrm{K}$, ammonium and nitrate, but did not detect a large increase in divalent cations or suspended sediments (Schaefer et al. 2000). Likewise, at the plot scale, we did not observe an accelerated loss of surface litter after the two hurricanes, which would have suggested increased erosion rates. Instead, we observed transient increases in surface litter due to defoliation following hurricanes Hugo and Georges, followed by rapid microbial decomposition (Silver et al. 1996; Ostertag et al. 2003). Soil and ecosystem recovery following erosion is likely to follow a very different trajectory, due to the rapid export of organic $\mathrm{C}$ and nutrients from shallow soil horizons (Walker 1991; Walker et al. 1991, 1996).

\section{Conclusion}

Vegetation structure, C, and nutrient pools showed differential responses to biomass removal and multiple hurricanes. Aboveground vegetation showed the strongest response to multiple disturbances. Land clearing resulted in heavy colonization by lightdemanding pioneers rather than more shade-tolerant late successional species. These pioneers were less resistant to hurricane damage and experienced high mortality due to Hurricane Georges 9 years later. Live fine root biomass was low for many years after clearing, with root re-growth in the cleared plots recovering only in the ninth year of the experiment. Higher nutrient availability in the cleared plots, combined with the tendency of many pioneers to allocate more resources to stem growth, may have suppressed root development during the initial stages of succession.

Soil $\mathrm{C}$ showed no apparent response to multiple disturbances, probably because it was well-buffered against change by the large size of the total soil $\mathrm{C}$ pool. Phosphorus, on the other hand, was relatively responsive to disturbance and vegetation reorganization. Reductions in aboveground biomass were associated with significant increases in soil $\mathrm{P}$, presumably due to decreased plant uptake and assimilation. Base cations showed an intermediate response to disturbance and vegetation re-structuring. Biomass removal accelerated base cation losses by reducing plant sequestration and curtailing litterfall inputs in the first year after clearing. This effect, however, was relatively short-lived for the divalent base cations ( $\mathrm{Ca}$ and $\mathrm{Mg}$ ), and soil pools returned to baseline levels by the second year after clearing. Potassium showed a longer recovery trajectory, although the basis for this pattern is still uncertain. These data indicate that while plant communities are vulnerable to the effects of multiple disturbances, the soils of subtropical wet forests are relatively resilient to both localized and large-scale perturbations, provided there are no land slides or surface erosion.

Acknowledgements Many thanks to the International Institute of Tropical Forestry for providing logistical and technical support. Thanks are also owed to M.J. Sánchez, E. Lopez and A.W. Thompson for laboratory assistance. R. Roderick-Jones and S. Moya provided crucial field assistance. Two anonymous referees provided invaluable comments that greatly improved the quality of this manuscript. This project was supported by grants from the USDA Forest Service to W.L.S., the A.W. Mellon Foundation, and is part of research activities of the California Agricultural Experiment Station (7069-MS to W.L. S.). Additional funds were provided by BSR-8811902, DEB9411973, DEB-008538, and DEB-0218039 to the Institute of Tropical Ecosystem Studies (ITES), University of Puerto Rico (UPR), and USDA International Institute of Tropical Forestry (IITF) as part of the LTER Program in the Luquillo Experimental Forest.

Open Access This article is distributed under the terms of the Creative Commons Attribution Noncommercial License which permits any noncommercial use, distribution, and reproduction in any medium, provided the original author(s) and source are credited.

\section{References}

Aide TM, Zimmerman JK, Herrera L, Rosario M, Serrano M (1995) Forest recovery in abandoned tropical pastures in Puerto Rico. For Ecol Manag 77:77-86

Aide TM, Zimmerman JK, Rosario M, Marcano H (1996) Forest recovery in abandoned cattle pastures along an elevational gradient in northeastern Puerto Rico. Biotropica 28:537-548. doi:10.2307/2389095

Aide TM, Zimmerman JK, Pascarella JB, Rivera L, MarcanoVega $H$ (2000) Forest regeneration in a chronosequence of 
tropical abandoned pastures: Implications for restoration ecology. Restor Ecol 8:328-338. doi:10.1046/j.1526100x.2000.80048.x

Beard KH, Vogt KA, Vogt DJ, Scatena FN, Covich AP, Sigurdardottir R, Siccama TG, Crowl TA (2005) Structural and functional responses of a subtropical forest to 10 years of hurricanes and droughts. Ecol Monogr 75:345-361. doi:10.1890/04-1114

Beinroth F (1982) Some highly weathered soils of Puerto Rico: 1. Morphology, formation and classification. Geoderma 27:1-74. doi:10.1016/0016-7061(82)90047-7

Bloom AJ, Chapin FS III, Mooney HA (1985) Resource limitation in plants - an economic analogy. Annu Rev Ecol Syst 16:363-392

Bonnet JA (1939) The nature of laterization as revealed by chemical physical and mineralogical studies of a lateritic soil profile from Puerto Rico. Soil Sci 48:25-40. doi:10.1097/00010694-193907000-00003

Brokaw NVL (1985) Gap-phase regeneration in a tropical forest. Ecol 66:682-687. doi:10.2307/1940529

Brokaw NVL (1987) Gap-phase regeneration of three pioneer tree species in a tropical forest. J Ecol 75:9-19. doi: $10.2307 / 2260533$

Brokaw NVL (1998) Cecropia schreberiana in the Luquillo Mountains of Puerto Rico. Bot Rev 64:91-120. doi:10.1007/BF02856580

Cavelier J, Estevez J, Arjona B (1996) Fine-root biomass in three successional stages of an Andean cloud forest in Colombia. Biotropica 28:728-736. doi:10.2307/2389059

Chapin FS III (1980) The mineral nutrition of wild plants. Annu Rev Ecol Syst 11:233-260. doi:10.1146/annurev. es.11.110180.001313

Chapin FS III (1991) Integrated responses of plants to stress: a centralized system of physiological responses. Bioscience 41:29-36. doi:10.2307/1311538

Chinea JD (1999) Changes in the herbaceous and vine communities at the Bisley Experimental Watersheds, Puerto Rico, following Hurricane Hugo. Can J Res 29:1433-1437. doi:10.1139/cjfr-29-9-1433

Cuevas E, Brown S, Lugo AE (1991) Above- and belowground organic matter storage and production in tropical pine plantation and a paired broadleaf secondary forest. Plant Soil 135:257-268. doi:10.1007/BF00010914

Denslow JS, Ellison AM, Sanford RE (1998) Treefall gap size effects on above- and below-ground processes in a tropical wet forest. J Ecol 86:597-609. doi:10.1046/j.13652745.1998.00295.x

Emanuel K (2005) Increasing destructiveness of tropical cyclones over the past 30 years. Nat 436:686-688. doi:10.1038/nature03906

Ewel JJ, Berish C, Brown B, Price N, Raich JW (1981) Slash and burn impacts on a Costa Rican wet forest site. Ecol 62:816-829. doi:10.2307/1937748

Fu S, Coleman DC, Schartz R, Potter R, Hendrix PF, Crossley DA $\mathrm{Jr}(2000){ }^{14} \mathrm{C}$ distribution in soil organisms and respiration after the decomposition of crop residue in conventional tillage and no-till agroecosystems at Georgia Piedimont. Soil Tillage Res 57:31-41. doi:10.1016/S0167-1987(00)00133-1

Guariguata MR, Ostertag R (2001) Neotropical secondary forest succession: changes in structural and functional characteristics. For Ecol Manag 148:185-206
Holdridge LR, Grenke WC, Hatheway WH, Liang T, Tosi JA Jr (1971) Forest environments in tropical life zones. Pergamon, New York

Hubbell SP, Foster RB, O'Brien ST, Harms KE, Condit R, Wechsler B, Wright SJ, de Lao SL (1999) Light-gap disturbances, recruitment limitation, and tree diversity in a neotropical forest. Science 283:554-557. doi:10.1126/ science.283.5401.554

Johnson CE, Romanowicz RB, Siccama TG (1997) Conservation of exchangeable cations after clear-cutting of a northern hardwood forest. Can J Res 27:859-868. doi:10.1139/cjfr-27-6-859

Johnson DW, Kelly JM, Swank WT, Cole DW, Van Miegroet H, Hornbeck JW, Pierce RS, Van Lear D (1988) The effects of leaching and whole-tree harvesting on cation budgets of several forests. J Environ Qual 17:418-424

Johnston MH (1992) Soil-vegetation relationships in a tabonuco forest community in the Luquillo Mountains of Puerto Rico. J Trop Ecol 8:253-263

Jones RC, Hudnall WH, Sakai WS (1982) Some highly weathered soils of Puerto Rico: 2. Mineralogy. Geoderma 27:75-138. doi:10.1016/0016-7061(82)90048-9

Kisselle KW, Garrett CJ, Fu S, Hendrix PF, Crossley DA, Coleman DC, Potter RL (2001) Budgets for root-derived $\mathrm{C}$ and litter-derived $\mathrm{C}$ : comparison between conventional tillage and no tillage soils. Soil Biol Biochem 32:10671075. doi:10.1016/S0038-0717(01)00012-8

Little E, Wadsworth FH (1989) Common trees of Puerto Rico. Reprint of agricultural handbook 249. USDA, Washington, DC

Lugo AE, Scatena FN (1996) Background and catastrophic tree mortality in tropical moist, wet, and rain forests. Biotropica 28:585-599. doi:10.2307/2389099

Marin-Spiotta E, Swanston CW, Torn MS, Silver WL, Burton SD (2008) Chemical and mineral control of soil carbon turnover in abandoned tropical pastures. Geoderma 143:49-62. doi:10.1016/j.geoderma.2007.10.001

Matson PA, Vitousek PM, Ewel JJ, Mazzarino MJ, Robertson GP (1987) Nitrogen transformations following tropical forest felling and burning on a volcanic soil. Ecol 68:491502. doi: $10.2307 / 1938454$

McDowell WH, McSwiney CP, Bowden WB (1996) Effects of hurricane disturbance on groundwater chemistry and riparian function in a tropical rain forest. Biotropica 28:577-584. doi: $10.2307 / 2389098$

Nelson DW, Sommers LE (1982) Total carbon, organic carbon and organic matter. In: Page AL (ed) Methods of soil analysis, part 2. Chemical and microbiological properties. American Society of Agronomy, Madison, pp $570-571$

Nepstad DC, Verissimo A, Alencar A, Nobre C, Lima E, Lefebvre P, Schlesinger P, Potter C, Moutinho P, Mendoza E, Cochrane M, Brooks V (1999) Large-scale impoverishment of Amazonian forests by logging and fire. Nat 398:505-508. doi:10.1038/19066

Olander LP, Scatena FN, Silver WL (1998) Impacts of disturbance initiated by road construction in a subtropical cloud forest in the Luquillo Experimental Forest, Puerto Rico. For Ecol Manag 109:33-49

Ostertag R (1998) Belowground effects of canopy gaps in a tropical wet forest. Ecol 79:1294-1304 
Ostertag R, Scatena FN, Silver WL (2003) Forest floor decomposition following hurricane litter inputs in several Puerto Rican forests. Ecosyst 6:261-273. doi:10.1007/ s10021-002-0203-8

Ostertag R, Silver WL, Lugo AE (2005) Factors affecting mortality and resistance to damage following hurricanes in a rehabilitated subtropical moist forest. Biotropica 37:1624

Ovington J, Olson JS (1970) Biomass and chemical content of El Verde lower montane rain forest plants. In: Odum $\mathrm{H}$, Pigeon RF (eds) A tropical rain forest: a study of irradiation and ecology at El Verde, Puerto Rico. US AEC, National Technical Information Service, Springfield, pp $\mathrm{H} 55-\mathrm{H} 77$

Paine RT, Tegner MJ, Johnson EA (1998) Compounded perturbations yield ecological surprises. Ecosyst 1:535545. doi:10.1007/s100219900049

Pascarella JB, Aide TM, Zimmerman JK (2004) Short-term response of secondary forests to hurricane disturbance in Puerto Rico, USA. For Ecol Manag 199:379-393

Payette S, Delwaide A (2003) Shift of conifer boreal forest to lichen-heath parkland caused by successive stand disturbances. Ecosyst 6:540-550. doi:10.1007/s10021-0020182-9

Picket STA, White RB (1985) The ecology of natural disturbance and patch dynamics. Academic, San Diego

Platt WJ, Connell JH (2003) Natural disturbances and directional replacement of species. Ecol Monogr 73:507-522. doi:10.1890/01-0552

Platt WJ, Beckage B, Dorien RF, Slater HH (2002) Interactions of large-scale disturbances: prior fire regimes and hurricane mortality of savanna pines. Ecol 83:1566-1572

Raich JW (1980) Fine roots regrow rapidly after forest felling. Biotropica 12:231-232. doi:10.2307/2387982

Raich JW (1983) Effects of forest conversion on the carbon budget of a tropical soil. Biotropica 15:177-184. doi: $10.2307 / 2387826$

Scatena FN (1989) An introduction to the physiography and history of the Bisley Experimental Watersheds Luquillo Mountains Puerto Rico. US Forest Service General Technical Report, New Orleans

Scatena FN, Larsen MC (1991) Physical aspects of Hurricane Hugo in Puerto Rico. Biotropica 23:317-323. doi: $10.2307 / 2388247$

Scatena FN, Silver WL, Siccama TG, Johnson A, Sanchez MJ (1993) Biomass and nutrient content of the Bisley Experimental Watersheds, Luquillo Experimental Forest, Puerto Rico, before and after Hurricane Hugo, 1989. Biotropica 25:15-27. doi:10.2307/2388975

Scatena FN, Moya S, Estrada C, Chinea JD (1996) The first five years in the reorganization of aboveground biomass and nutrient use following Hurricane Hugo in the Bisley Experimental Watersheds, Luquillo Experimental Forest, Puerto Rico. Biotropica 28:424-440. doi:10.2307/ 2389086

Schaefer DA, McDowell WH, Scatena FN, Asbury CE (2000) Effects of hurricane disturbance on stream water concen- trations and fluxes in eight tropical forest watersheds of the Luquillo Experimental Forest, Puerto Rico. J Trop Ecol 16:189-207. doi:10.1017/S0266467400001358

Silver WL, Vogt KA (1993) Fine root dynamics following single and multiple disturbances in a subtropical wet forest ecosystem. J Trop Ecol 81:729-738

Silver WL, Scatena FN, Johnson AH, Siccama TG, Sanchez MJ (1994) Nutrient availability in a montane wet tropical forest: spatial patterns and methodological considerations. Plant Soil 164:129-145. doi:10.1007/BF00010118

Silver WL, Scatena FN, Johnson AH, Siccama TG, Watt F (1996) At what temporal scales does disturbance affect belowground nutrient pools? Biotropica 28:441-457. doi: $10.2307 / 2389087$

Silver WL, Kueppers LM, Lugo AE, Ostertag R, Matzek V (2004) Carbon sequestration and plant community dynamics following reforestation of tropical pasture. Ecol Appl 14:1115-1127. doi:10.1890/03-5123

Smith DM, Larson BC, Kelty M, Ashton PMS (1997) The practice of silviculture: applied forest ecology. Wiley, New York

Sollins P, Robertson GP, Uehara G (1988) Nutrient mobility in variable and permanent-charge soils. Biogeochemistry 6:181-200. doi:10.1007/BF02182995

Sousa WP (1984) The role of disturbance in natural communities. Annu Rev Ecol Syst 15:535-391. doi:10.1146/ annurev.es.15.110184.002033

Sposito G (1989) The chemistry of soils. Oxford University Press, Oxford

Thompson J, Brokaw NVL, Zimmerman JK, Waide RB, Everham EM III, Lodge JD, Taylor CM, Garcia-Montiel D, Fluet M (2002) Land use history, environment, and tree composition in a tropical forest. Ecol Appl 12:1344-1363. doi:10.1890/1051-0761(2002)012[1344:LUHEAT]2.0. $\mathrm{CO} ; 2$

Tiessen H, Cuevas E, Chacon P (1994) The role of soil organic matter in sustaining soil fertility. Nat 371:783-785. doi: $10.1038 / 371783 \mathrm{a} 0$

Uriarte M, Rivera LW, Zimmerman JK, Aide TM, Power AG, Flecker AS (2004) Effects of land use history on hurricane damage and recovery in a neotropical forest. Plant Ecol 174:49-58. doi:10.1023/B:VEGE.0000046058.00019.d9

Walker LR (1991) Tree damage and recovery from Hurricane Hugo in Luquillo Experimental Forest, Puerto Rico. Biotropica 23:379-385. doi:10.2307/2388255

Walker LR, Lodge DJ, Brokaw NVL, Waide RB (1991) An introduction to hurricanes in the Caribbean. Biotropica 23:313-316. doi: $10.2307 / 2388246$

Walker LR, Zarin DJ, Fetcher N, Myster RW, Johnson AH (1996) Ecosystem development and plant succession on landslides in the Caribbean. Biotropica 28:566-576. doi: $10.2307 / 2389097$

Zimmerman JK, Everham EM III, Waide RB, Lodge DJ, Taylor CM, Brokaw NVL (1995) Responses of tree species to hurricane winds in subtropical wet forest in Puerto Rico: implications for tropical tree life histories. J Ecol 82:911921. doi: $10.2307 / 2261454$ 